\title{
Serum Zinc Status of Neonates With Seizure.
}

\author{
Olia Sharmeen ${ }^{1}$, Md. Abid Hossain Mollah ${ }^{2}$, Md. Hasanur Rashid ${ }^{3}$, Shamshad B. Quaraishi ${ }^{4}$ \\ ${ }^{1}$ Department of Paediatric Oncology, National Institute of Cancer Resarch \& Hospital, Mohakhali,Dhaka.D ${ }^{2}$ Department of Paediatrics, Dhaka \\ Medical College Hospital. ${ }^{3}$ Department of Respiratory Medicine, National Institute of Diseases Chest \& Hospital Dhaka. ${ }^{4}$ Chemistry Division, Atomic \\ Energy Center. Dhaka.
}

\begin{abstract}
:
Background: Seizure is a common neurological disorder in neonatal age group1. Primary metabolic derangement is one of the important reason behind this convulsion during this period. Among primary metabolic derangement hypoglycemia, is most common followed by hypocalcaemia, hypomagnesaemia, low zinc status etc. As causes of many cases of convulsion remain unknown in neonates, Objectives: to see the zinc status in the sera of neonate with convulsion. So that if needed early intervention can be taken up and thereby prevent complications. Method: A total of 50 neonates (1-28 days) who had convulsion with no apparent reasons of convulsion were enrolled as cases and 50 healthy age and sex matched neonates were enrolled as controls. After a quick clinical evaluation serum zinc status was estimated from venous blood by atomic absorption method in Chemistry Division, Atomic Energy Centre. Low zinc was considered if serum value was $<0.7 \mathrm{mg} / \mathrm{L}$. Results: Among a total of 50 cases $6 \%$ had low zinc value \& $2 \%$ of controls also had low zinc level. The mean serum zinc level of cases and controls were $1.57 \pm 0.95$ and $2.37 \pm 1.06 \mathrm{mmol} / 1$ respectively (p<0.01). Conclusion: From the study it is seen that low zinc value is an important cause of neonatal seizure due to primary metabolic abnormalities. So early recognition and treatment could save these babies from long term neurological sequelies.
\end{abstract}

Key words: Neonate, Seizure, low zinc level.

[BSMMU J 2014; 7 (2) : 99-102]

\section{Introduction:}

Seizure is a common neurological disorder in neonates. During neonatal period manifestations of seizure are more common than at any other period of life. Neonates are at particular risk because seizure among them can be a manifestation of metabolic, toxic, infectious and structural disorder. ${ }^{1}$ The manifestations of neonatal, seizure are extremely subtle 2,3 . Repetitive lip smacking, cycling or swimming movements, blinking, nystagmus, deviation of eye and alteration of respiratory rate including apnea can be manifestations of neonatal seizure which is sometimes difficult to distinguish from neonatal movement ${ }^{1}$.

Address for Correspondence: Dr. Olia Sharmeen. Assistant Professor Paediatric Oncology National Institute of Cancer Resarch \& Hospital Dhaka. Mobile : 01819241888. E mail : oliasharmeen@gmail.com
As many as $20 \%$ newborn in intensive care unit may have seizure activity at sometime ${ }^{4,5}$ The overall prevalence is as low as $0.5 \%$ in term and as high as $21 \%$ in preterm babies $^{6,7}$.

Presence of seizure does not constitute a diagnosis but it is a symptom of an underlying central nervous system (CNS) disorder due to systemic or biochemical disturbances ${ }^{8}$. Biochemical disturbances occur frequently in the neonatal seizure. In their presence, it is difficult to control seizure and there is a risk of further brain damage. Early recognition and prompt treatment of biochemical disturbance is essential for optimal management and satisfactory long term outcome ${ }^{5}$. Different types of biochemical abnormalities can cause seizure like hypocalcaemia, hypoglycemia, hypomagnesemia, hypernatremia, 
hyponatremia, low zinc status etc ${ }^{8,9,10}$. Though several studies on the association with neonatal seizure had been carried out in our country but very few references exist with that of serum zinc. So it is important to measure serum zinc status in neonates with seizure, who had not any apparent reasons of convulsion. It is important to know as because early recognition and treatment can significantly influence the better outcome.

\section{Method:}

This case control study was carried out in neonatal care unit of Dhaka Medical College Hospital over 1 (one) year period from July 2003 to June 2004 in cooperation with the chemistry division, Atomic Energy Center, Dhaka. A total of 100 babies were studied, among them 50 neonates were enrolled as cases, they had convulsion but had no obvious cause of convulsion behind it and 50 age, sex and body weight matched neonates were enrolled as controls who were admitted to neonetat ICU for other illness not known to cause convulsion.. Neonates who had history of fever, septicemia, meningitis, perinatal asphyxia, birth injuries, CNS anomalies or other obvious causes of convulsion were excluded. Informed consent was obtained from all the parents. Detailed history was taken about presenting illness. Antenatal, natal and postnatal history, socioeconomic history, family history regarding consanguinity of marriage between parents, affection of previous sibs, family history of epilepsy were taken very carefully. A through physical examination was done in every neonate. Convulsion was treated by per-rectal benzodiazepine $(0.5 \mathrm{mg} / \mathrm{kg})$, then with all aseptic precautions, $3 \mathrm{ml}$ of venous blood was collected from each subject for the measurement of serum zinc along with other elements which may cause convulsion like serum calcium, magnesium \& blood glucose in addition to routine investigations like complete blood count, C reactive protean. Blood was allowed to clot at room temperature \& centrifuged for 10 minutes, separated serum was stored frozen until used for the measurement of Serum zinc by atomic absorption method in Chemistry Division, Atomic Energy Center. Low zinc is considered if serum level is less than $0.7 \mathrm{mg} / \mathrm{L}$. Data were analyzed in SPSS using appropriate statistical tools. A p value of $<$ 0.05 were taken as a level of significance.

\section{Results:}

Among 50 cases, $60 \%$ were male and $40 \%$ were female, $80 \%$ were within $1^{\text {ST }} 5$ day and remaining $20 \%$ were between 6-28 days, distribution of controls were also similar (Fig-1, Fig-2).Mean age of both cases and controls were 4.37 and 4.22 days respectively. Mean weight of nearly $40 \%$ of cases and equal number of controls were between $2.8 \pm 0.24$ and $60 \%$ of cases and controls were $2.1 \pm 0.36$. Seventy four percent babies were preterm and $26 \%$ babies were term. Sixty four percent babies had convulsion for less than 5 minutes duration and $36 \%$ had convulsion for more than 5 minute (Table-I). Of different types of convulsion focal was found in $24 \%$, subtle in $36 \%$ and mixed in $40 \%$ cases (Fig-3). Low zinc status was present in $6 \%$ of cases. It was noted that about $2 \%$ of controls also had low zinc level, though they had no manifestation The mean serum zinc level of cases and controls were $1.57 \pm 0.95$ and $2.37 \pm 1.06 \mathrm{mmol} / \mathrm{l}$ respectively $(\mathrm{p}<0.01)$.

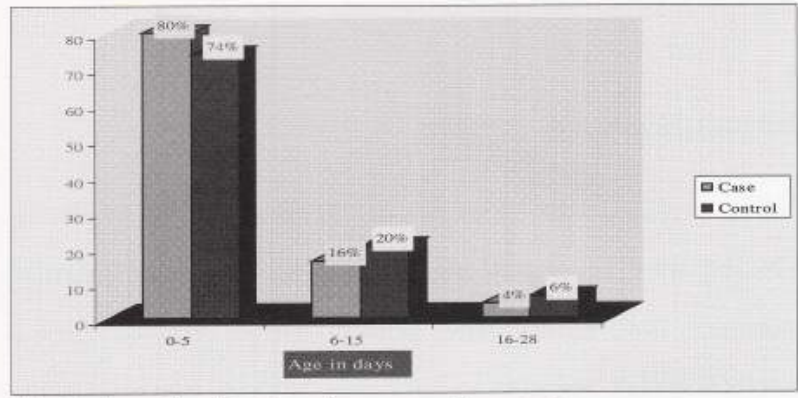

Fig-1: Age distribution of cases and controls.

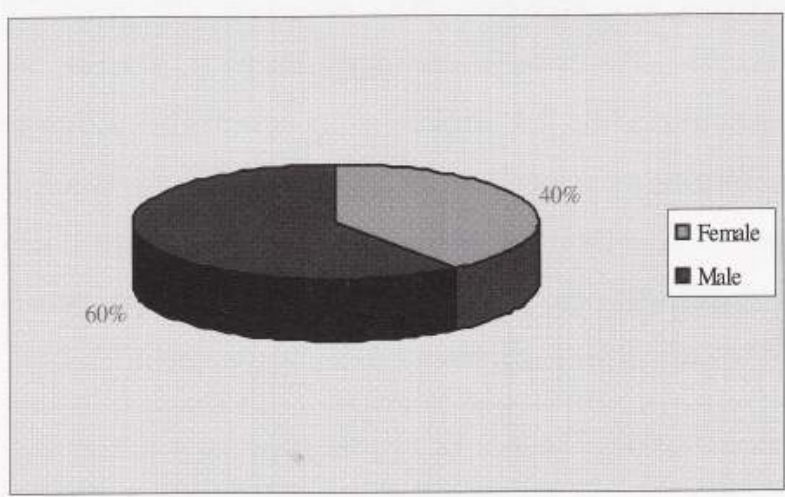

Fig-2: Sex incidence of cases and controls. 


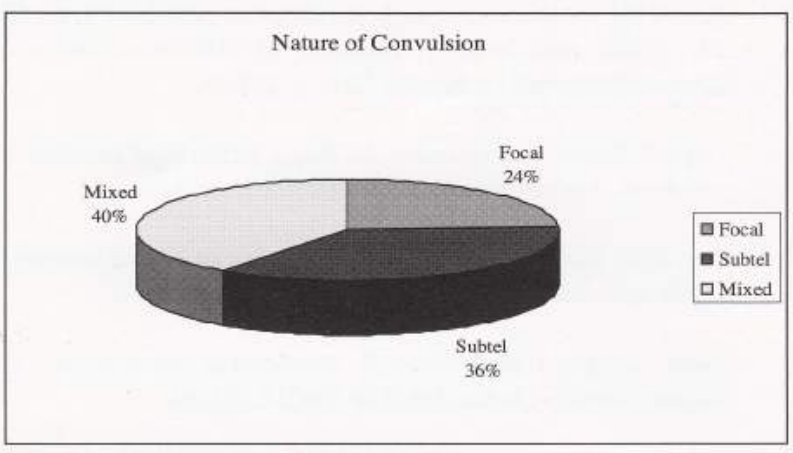

Fig- 3: Nature of convulsion

Table- I

Number and percentage of neonates by duration of convulsion

\begin{tabular}{lll}
\hline Duration (in minute) & Case & Control \\
\hline & $(\mathrm{n}=50)$ & $(\mathrm{n}=50)$ \\
$<5$ & $32(64 \%)$ & - \\
$5-30$ & $18(36 \%)$ & - \\
\hline
\end{tabular}

Table-II

Presentation of biochemical abnormalities in cases and controls.

\begin{tabular}{lll}
\hline Total No & $\begin{array}{l}\text { No of low Zinc level } \\
\text { in Patients }\end{array}$ & Percentage \\
\hline Case & & \\
$(n=50)$ & 03 & $06 \%$ \\
Control & & $02 \%$ \\
$(n=50)$ & 01 & 0 \\
\hline
\end{tabular}

\section{Table - III}

Mean values of serum Zinc in cases and controls.

Biochemical Case $(n=50)$ Control $(n=50)$ p value
changes

Serum Zinc $\quad 1.57 \pm 0.95 \quad 2.37 \pm 1.06 \quad 0.01$

$\mathrm{mol} / \mathrm{L}$ ( mean

$\pm \mathrm{SD})$

\section{Discussion :}

In this study, serum zinc status were studied in 50 convulsive neonates who had no apparent cause of seizure and were compared with age and sex matched controls.
Kumar et al ${ }^{7}$ in a study showed that primary metabolic disorder accounted for $25 \%$ cause of neonatal convulsion. In a study which was carried out over 2 years period on neonatal convulsion by Cockburn et $\mathrm{al}^{9}$ found that $55 \%$ of neonatal convulsions were due to primary disturbances of mineral metabolism. Metabolic cause of convulsion is common in Bangladesh may be due to delayed and infrequent brest feeding, faulty feeding practices etc. This is in contrast to reports from western countries where improvement in infant feeding practices have made this category as uncommon cause of seizure ${ }^{7}$.

Duration of convulsion has prognostic value. Seizures lasting more than 30 minutes bears a poor prognosis ${ }^{8}$ In this study $64 \%$ of the babies had convulsions of less than 5 minutes and $36 \%$ had convulsions lasting 5-30 minutes. Clinical observation without EEG may underestimate the true incidence or duration of neonatal seizure. Electrical seizure may persist without clinical signs following an introduction of anticonvulsant ${ }^{11}$. Clinical recognition of seizures is impossible in babies, who have been paralyzed therapeutically. EEG monitoring was not done in this study due to lack of facility.

Among primary metabolic abnormalities in neonates, hypocalcaemia is the most common followed by hypoglysemia, hypomagnesemia \& low zinc status ${ }^{6}$. Sood A et al ${ }^{5}$ in a study of biochemical abnormalities in neonatal seizure showed that most common cause of seazure due to primary metabolic abnormalities were hypoglycemia followed by hypocalcaemia \& low zinc level.

A study was done by Mollah AH et al, in our country over 42 cases of febrile convulsion \& 30 controls of fever without convulsion. The study concludes that a significantly lower zinc exists in children with febrile convulsion. However no relationship was found between zinc 
status with age, sex, degree $\&$ duration of convulsion ${ }^{12}$. Gunduz $\mathrm{Z}$ et al in a study of serum \& CSF zinc levels in children with febrile convulsions could not observe any relationship between zinc levels of serum \& CSF \& the degree \& duration of sizure ${ }^{13}$. In the present study $6 \%$ patient had low zinc value and $2 \%$ of controls also had low zinc but not associated with convulsion. Mean serum zinc was $1.57 \pm 0.95 \mathrm{mmol} / \mathrm{L}$ in cases which was $(\mathrm{p}<0.01)$ lower than the value in controls $2.37 \pm 1.06 \mathrm{mmol} / \mathrm{l}$. Kumar et al in their study found that mean serum zinc in neonatal convulsion cases was significantly lower than that of the value in controls ?

\section{Conclusion:}

From the study it is revealed that low zinc level can also be a cause of neonatal seizure due to primary metabolic abnormalities, where no cause of seizure is identified. So early recognition and treatment could save these babies from long term neurological problems. Further studies with large sample size covering both urban and rural population over a wide range of time may give more information about the biochemical changes in neonatal convulsions in our country.

\section{References:}

1. Halsam RHA. Neonatal seizure. In: Behrman RE, Kliegman RM, Jenson HB. Nelson text book of pediatrics, 17 th edn. Philadelphia, W B Saunders Company 2004; p:1813-28.
2. Rennic JM. Neonatal neurology. In: Mclntosh N,Helms PJ, Smyth RL. Forfar and Arneil's Textbook of Pediatrics, 6th edn. Newyork,Churchill Livingston 2003; p: 244-49.

3. Gupte S. Neonatal convulsions. In: Gupte S. The short textbook of pediatrics, 4 th edn.New Delhi, Jaypee 2003; p: 342.

4. Seay AR, Bary PF. Significance of seizures in infants weighing $<2500$ gms. Arch-neurol 1977; 34:381-82.

5. Sood A, Grover N, Sharma R. Biochemical abnormalities in neonatal seizures. Indian J Pediatr 2003; 3:221-24.

6. Brown JK, Cockburn F, Forfur JO. Clinical and chemical correlaters in convulsions of the newborns. Lancet 1972; 1:135-39.

7. Kumar A, Gupta V, Kachhawaha JS, Singla PN. Biochemical abnormalities in neonatal seizure. Indian J of pediatr 1995; 323: 424-28.

8. Kliegmen RM. Fetal and Neonatal Medicine. In : Behrman RE, Kilegmen RM. Nelson Essentials of Paediatrics, 5thedn.Philadelphia,WB Sunders company 2005; p:202-206.

9. Cockburn F, Brown JK, Belton NR, Forfar JO. Neonatal Convulsions associated with primary disturbance of calcium, phosphorous and magnesium metabolism. Arch of disease of childhood 1973; 48:99-108.

10. Raisz LG. Physiology and pharmacologic regulation of bone absorption. N Engl J Med 1997; 282:909-15

11. Wasterlain CG, Duffy TE. Status epilepticus in premature infants. Arch Neurol 2003; 33:821-827.

12. Mollah MAH, Day PR, Tarafdar SA, Akter S. Zinc in CSF of patients with febrile convulsion. Indian J Pediatr 2002; 69(10): $859-861$

13. Gunduz Z, Vavuz I, Koparl M, Kumandas S, Saraymen F. Serum \& Cerebropinal fluid Zine levels in children with febrile convulsions. Pediatr International 1996; 38(3): 237-241. 